\title{
Biotech Products as Drug Leads
}

With increasing pressures to develop cost-effective drugs that deliver real benefit, biotech and pharmaceutical companies alike are eyeing the top ten money-producing drugs as possible candidates for small molecule development (see Table 1). The logic of this approach seems indisputable: Taking a drug that already brings in anywherefrom $\$ 200$ million to $\$ 700$ million in U.S. sales and making it orally deliverable not only adds real benefit but should also streamline manufacturing costs.

To the sophisticated drug developer, biotech's top ten list represents a blueprint for small molecule development based on more than simple financial success. Most of these drugs belong to the hematopoietic superfamily - molecules whose receptor-ligand interaction looks to be structurally similar. Close cousins in this family include growth hormone, $\mathrm{t}-\mathrm{Pa}, \mathrm{EPO}$, and the GCSF. More distant, but still related cousins, are the interferons. The vaccines and insulin are unrelated. With nearly $\$ 3$ billion dollars in U.S. sales streaming in from this to parrot interactions at contact interfaces by paring down large biotech proteins to a more manageable size. Alternatively, they attempt to construct organic compounds that mimic the overall shape of the drug.

But the other definition of mimesis is to copy the manner or expression of something. The work of Wells' group in defining "functional epitopes" in the human growth hormone complex represents an important step toward learning to design drugs based on this meaning of mimesis. Small molecules that function like their larger biotech predecessors may have very little in common in terms of shape or structure. By focusing on function rather than structure, they believe they can design molecules that will in turn agonize or antagonize a receptor in very specific ways. Some day this may mean biotech-based small molecules that will no longer produce the unwanted side effects produced by the drug's interaction with more than one type of receptor.

Hand in hand with this shift to the molecule drugs they envision from this approach duplicate the function of current biotech drugs but look nothing like existing recombinants.

\section{Mix and Match}

It is unlikely that any one of these approaches will turn out to be the hands-down favorite. Depending on the target, and the experience of the drug development team, all of these approaches may come to the fore at various stages in the $R \& D$ path. For example, an interesting synthesis of these methods is currently underway at Merck (Whitehouse Station, NJ). Roy Smith and his coworkers wanted to design a small molecule replacement for growth hormone. To accomplish this they took the opposite tack from the normal approach of trying to mimic the existing biotech compound. They began by taking a systems-wide look at how they might set up assays that could detect a molecule capable of stimulating the natural secretion of growth hormone. Once the assays were established. they then selectively screened Merck's proprietary

\begin{tabular}{|c|c|c|c|c|c|c|}
\hline 5 & & & & $0^{\circ}$ & & $p^{p}$ \\
\hline $\begin{array}{l}719 \\
587 \\
572\end{array}$ & $\begin{array}{l}\text { Filgrastim } \\
\text { Epoetin } \\
\alpha \text {-Interferon }\end{array}$ & $\begin{array}{l}\text { Neupogen } \\
\text { Epogen } \\
\text { Intron A }\end{array}$ & $\begin{array}{l}\text { Neutropenia } \\
\text { Anemia } \\
\text { Immune Protection }\end{array}$ & $\begin{array}{l}\text { Amgen } \\
\text { Amgen } \\
\text { Biogen }\end{array}$ & $\begin{array}{l}\text { Amgen } \\
\text { Amgen } \\
\text { Schering-Plough }\end{array}$ & \multirow{2}{*}{$\begin{array}{l}\text { Feb-91/Jun-94 } \\
\text { Jun-89 } \\
\text { Jun-86//Jun-88/Nov-88 } \\
\text { Feb-91/Jul-92 } \\
\text { Oct-82 } \\
\text { Dec-90 } \\
\text { Sep-89 } \\
\text { Jul-86 } \\
\text { Nov-87/Jun-90 } \\
\text { Oct-85 } \\
\text { Jun-86/Nov-88 }\end{array}$} \\
\hline $\begin{array}{l}560 \\
500 \\
480 \\
245 \\
236 \\
217 \\
172\end{array}$ & $\begin{array}{l}\text { rh insulin } \\
\text { Epoetin } \\
\text { Vaccine } \\
\text { Vaccine } \\
\text { rt-PA } \\
\text { th growth hormone } \\
\alpha \text {-Interferon }\end{array}$ & $\begin{array}{l}\text { Humulin } \\
\text { Procrit } \\
\text { Egerix-B } \\
\text { Recombivax } \\
\text { Activase } \\
\text { Protropin } \\
\text { Roferon-A }\end{array}$ & $\begin{array}{l}\text { Diabetes } \\
\text { Anemia } \\
\text { Hepatitis B } \\
\text { Hepatitis B } \\
\text { Myo. infarction/embolism } \\
\text { Dwarfism } \\
\text { Leukemai/Kaposi }\end{array}$ & $\begin{array}{l}\text { Genentech } \\
\text { Amgen } \\
\text { Genentech } \\
\text { Chiron } \\
\text { Genentech } \\
\text { Genentech } \\
\text { Genentech }\end{array}$ & $\begin{array}{l}\text { Eli Lilly } \\
\text { Ortho-Biotech } \\
\text { SmithKline Beecham } \\
\text { Merck } \\
\text { Genentech } \\
\text { Genentech } \\
\text { Hoffmann-LaRoche }\end{array}$ & \\
\hline
\end{tabular}

superfamily so far, companies such as Genentech see continued research and development (R\&D) on this family tree as a way to further capitalize on an existing product base.

\section{Diverging Pathways}

When it comes to the question of how to design a small molecule to replace one of these large biotech proteins, the jury is still out. Drug developers have coined the term "small molecule mimetics" to describe this process, and the Greek root of word mimesis is illustrative of the approaches being tried. Most literally, mimesismeans "to imitate." But it is how you go about imitating something that defines your approach. On the one hand, you can repeat, or parrot what is there. For example, rational drug designers try functional mimics of biotech molecules is the panpharmaceutical explosion of interest in creating and searching combinatorial libraries. These so-called "irrational" approaches show little concern with structural or functional mechanisms beyond what they can learn from them in designing assays for selecting drug leads from large candidate pools.

Advocates of this approach say biology is too complicated to believe that one can repeatedly design small molecules based on either structural or functional epitopes. Instead, they suggest, the real payoff for drug design will come from linking all this mechanistic information into larger pathways. From these pathways, they claim, new points to intervene will emerge. The combinatorial library-derived small drug libraries to findleadcompounds.

These compounds were optimized by structure-based methods to the point where the team was certain about proof of principle. Convinced that the drug could work, they went on to create a second generation drug by developing a modular combinatorial library and screening again. The result of this synthesis of methods is a second generation compound that performs as much as ten times better than any lead developed previously during their research. convinced that this drug development strategy will eventually loop back to biotech: They believe the molecule they have developed is mimicking a natural hormone that remains to be discovered. -Stephen M. Edgington Smith and his collaborators are
TABLE 1.

The top ten grossing biotech drugs ranked by U.S, sales. 